\title{
Correction to: Evaluation of the impact of breastfeeding support groups in primary health centres in Andalusia, Spain: a study protocol for a cluster randomized controlled trial (GALMA project)
}

Isabel Rodríguez-Gallego ${ }^{1}$, Fatima Leon-Larios²* Cecilia Ruiz-Ferron² and Maria-de-las-Mercedes Lomas-Campos ${ }^{2}$

Correction to: BMC Public Health 20, 1129 (2020) https://doi.org/10.1186/s12889-020-09244-w

It was highlighted that in the original article [1] the given names and the family names of the authors were interchanged. The original article has been updated.

\section{Author details}

'Virgen del Rocío University Hospital (Seville), Centro Universitario de Enfermería Cruz Roja, University of Seville, Sevilla, Spain. ${ }^{2}$ Nursing

Department, Faculty of Nursing, Physiotherapy and Podiatry, University of

Seville, Sevilla, Spain

Published online: 23 September 2020

\section{Reference}

1. Isabel, et al. Evaluation of the impact of breastfeeding support groups in primary health centres in Andalusia, Spain: a study protocol for a cluster randomized controlled trial (GALMA project). BMC Public Health. 2020;20: 1129 https://doi.org/10.1186/s12889-020-09244-w.

The original article can be found online at https://doi.org/10.1186/s12889020-09244-w.

* Correspondence: fatimaleon@us.es

${ }^{2}$ Nursing Department, Faculty of Nursing, Physiotherapy and Podiatry, University of Seville, Sevilla, Spain

Full list of author information is available at the end of the article

(c) The Author(s). 2020 Open Access This article is licensed under a Creative Commons Attribution 4.0 International License, which permits use, sharing, adaptation, distribution and reproduction in any medium or format, as long as you give appropriate credit to the original author(s) and the source, provide a link to the Creative Commons licence, and indicate if changes were made. The images or other third party material in this article are included in the article's Creative Commons licence, unless indicated otherwise in a credit line to the material. If material is not included in the article's Creative Commons licence and your intended use is not permitted by statutory regulation or exceeds the permitted use, you will need to obtain permission directly from the copyright holder. To view a copy of this licence, visit http://creativecommons.org/licenses/by/4.0/ The Creative Commons Public Domain Dedication waiver (http://creativecommons.org/publicdomain/zero/1.0/) applies to the data made available in this article, unless otherwise stated in a credit line to the data. 